\title{
THE GROWTH OF TREATMENT THROUGH THE SCHOOL MEDICAL SERVICE, 1908-18
}

by

\section{J. DAVID HIRST *}

On 28 August 1907, the Education(Administrative Provisions) Act received the Royal Assent. ${ }^{1}$ One sub-clause in this measure gave local education authorities (LEAs)

The duty to provide for the medical inspection of children immediately before or at the time of or as soon as possible after their admission to a public elementary school, and on such other occasions as the Board of Education direct, and the power to make such arrangements as may be sanctioned by the Board of Education for attending to the health and physical condition of the children educated in public elementary schools. ${ }^{2}$

This sub-clause was the legal foundation for the School Medical Service in England and Wales, and the optional power it conferred was used by an increasing number of LEAs to provide medical treatment for schoolchildren found on inspection to have diseases or disabilities.

In his study of the social legislation of the Liberal government of 1906 to 1914, Bentley B. Gilbert has suggested that this development of sometimes quite extensive systems of medical treatment for schoolchildren was not wholly foreseen by the Parliamentarians debating the Bill. They had been the

victims of a political-administrative trick by which the evolution from personal medical inspection to personal medical care was blurred and disguised so that not even the House of Commons, let alone the public, had the opportunity to discuss the change in any detail. $^{3}$

Gilbert's argument suggests that the power to provide treatment was smuggled through Parliament almost unnoticed, allowing the subsequent development of systems of treatment by "ministerial order". 4

This interpretation has influenced several subsequent accounts of the development of the School Medical Service, among them that of Derek Fraser, who has suggested that

R. L. Morant, the active and influential Permanent Secretary of the Education Board, was anxious that the case for school medical treatment (which the Liberals were

*J. David Hirst, B.Sc.(Soc.), MA, Ph.D., Department of Social Theory and Institutions, University College of North Wales, Bangor, Gwynedd LL57 2DG.

\footnotetext{
${ }^{1}$ Hansard, 4th series, 182: 425.

2 Education (Administrative Provisions) Act 1907. Public General Acts, 7 Edw. VII, c. 43, cl. 13(i)(b).

3 Bentley B. Gilbert, The evolution of National Insurance in Great Britain, London, Michael Joseph, 1966,

${ }^{4}$ Ibid.
} p. 117. 
unwilling to accept) should be established by the revelations that would inevitably follow from the introduction of school medical inspection. He drew up the 1907 bill and in effect smuggled medical inspection through by surrounding it with other, much less significant administrative proposals. ${ }^{5}$

The absence of public controversy, the obscurity of the Act, and the vague phraseology of the optional power of "attending to the health and physical condition of the children" all support this interpretation. There is also the claim of Morant himself that he

knew ... but did not tell his Minister, that medical inspection would reveal such a mass of disease and defects that no government subsequently would be able to resist the demand of Local Education Authorities to provide treatment. Morant told me himself that he foresaw what would happen and meant it to happen because without these horrifying results of inspection there was no chance for a Bill authorising treatment. ${ }^{6}$

Morant has a justified reputation as an energetic, innovative, and visionary civil servant. ${ }^{7}$ But this status, his own claims, and those of his contemporary admirers that he created the School Medical Service "out of half a dozen lines in a second class measure", 8 have combined to suggest that the 1907 legislation was limited in its intentions, if not in its outcome.

This view, that treatment came subsequently to inspection, and then largely at the instigation of Morant and his administrative colleagues at the Board, has led to a relative neglect of the results of the 1907 Act by historians of social policy. Gilbert has dealt at some length with the debate within the medical profession on the treatment of schoolchildren, and with the problems encountered by the voluntary hospitals. ${ }^{9}$ In other accounts, references to the nature of the treatment provided, and the causes of its development, may be limited to references to the growth of the school clinic system. ${ }^{10}$

In 1918, LEAs were given a duty to provide treatment, in a clause using the same phraseology as the 1907 Act. ${ }^{11}$ By this time, the scope and method of medical treatment was already clear. Almost all authorities were offering treatment, and the school clinic was the most favoured means of giving it. The extent to which this was intended by the

${ }^{5}$ Derek Fraser, The evolution of the British welfare state, London, Macmillan, 1973, p. 138; see also J. R. Hay, The origins of the Liberal welfare reforms, 1906-1914, Studies in Economic and Social History for the Economic History Society, London, Macmillan, 1975, p. 44; Pat Thane, Foundations of the welfare state, London, Longmans, 1982; p. 77; and Deborah Dwork, War is good for babies and other young children, London, Tavistock, 1987, p. 184.

${ }^{6}$ Quoted in Violet Markham, Friendship's harvest, London, Reinhardt, 1956, pp. 200-1.

${ }^{7}$ For some accounts of Morant's career, see B. M. Allen, Sir Robert Morant, London, Macmillan, 1934; E. J. D. Eaglesham, 'The centenary of Sir Robert Morant', Br. J. educ. Stud., 1966, 12: 5-18; Violet Markham, 'Sir Robert Morant: Some personal reminiscences', Public Admin, 1950, 28: 249-60. For a more critical perspective on Morant, see T. Taylor, 'An early arrival of the Fascist mentality: Robert Morant's rise to power', J. educ. Admin. \& Hist., 1985, 17(2): 48-62.

${ }^{8}$ Sir George Newman, The building of a nation's health, London, Macmillan, 1939, pp. 467-8, quoted in G. R. Searle, The quest for national efficiency, Oxford, Blackwell, 1971, p. 244.

${ }^{9}$ Gilbert, op. cit., note 3 above, pp. 148-56.

${ }^{10}$ See, e.g., Fraser, op. cit., note 5 above, pp. 138-9; Thane, op. cit., note 5 above, pp. 77-8; Dwork, op. cit., note 5 above, p. 205; Department of Education and Science, The School Health Service 1908-1974, London, HMSO, 1975, pp. 8-11.

${ }^{11}$ Education Act 1918. Public General Acts, 8 \& 9 Geo. V, c. 39, cl. 2(i)(b). 


\section{J. David Hirst}

Parliamentarians who considered the Education (Administrative Provisions) Bill in 1907, and the degree to which the subsequent determination of the character of treatment was the work of Morant and Newman, is the subject of this article.

\section{THE ORIGINS OF THE 1907 LEGISLATION}

The obscurity of the 1907 Act is a product of its origins, for it was an attempt to resuscitate the non-controversial parts of the Liberal government's 1906 Education Bill, which had foundered on opposition in the House of Lords from the Established Church and Conservative peers. ${ }^{12}$ Before the 1907 Bill was introduced, negotiations took place between Government and Opposition to ensure that all clauses in the Bill would be accepted as non-contentious by the Unionists. ${ }^{13}$

The content of the 1907 Act and the phraseology of its clauses were therefore strongly influenced by the drafting of the abortive 1906 Bill. The Private Office papers dealing with the drafting and preparation of the 1906 Bill show that reference to medical inspection was not at first included. Nineteen (out of 21) preliminary drafts of the 1906 Bill survive, but not until the twelfth draft was there a sub-clause giving

Power to make such arrangements as may be sanctioned by the Board of Education for the inspection of public elementary schools with a view to acquiring information as to the health and physical condition of the children attending the school. ${ }^{14}$

This only gave authorization for a general survey of the health of school children, rather than permitting individual medical attention.

By the next extant draft, the clause had been revised into a form more closely resembling that of the 1907 Bill. Draft 100/14 included a

Power to make such arrangements as may be sanctioned by the Board of Education for attending to the health and physical condition of the children in public elementary schools. $^{15}$

This draft gave LEAs a power which, though still optional, offered wider scope for action. But no reference was now made to medical inspection. This had been subsumed

\footnotetext{
${ }^{12}$ See Peter G. Rowland, The last Liberal governments, 2 vols., vol. 1, The promised land 1905-1910, London, Barrie \& Rockliff, 1968, p. 85; R. Pattison, 'The Birrell Education Bill of 1906', J. educ. Admin \& Hist., 1973, 5(1): 34-41.

${ }^{13}$ PRO Ed24/128, Sir Willian Anson to A. J. Balfour, 27 February 1907; Sir Robert Morant to Anson, 1 March 1907. Where unpublished material is cited the appropriate record depository is identified by the abbreviation PRO (Public Record Office); BM (British Library manuscipt collection); BLPES (British Library of Political and Economic Science); GLRO (Greater London Record Office); HWCRO (Hereford branch of the Hereford and Worcester County Record Office) and GROLl (Llangefni branch of the Gwynedd Record Office).

${ }_{14}$ PRO Ed24/117, Education (England and Wales) Bill, draft 100/12, cl. 15(b), 26 March 1906. The history of the educational legislation planned for the first session of the new Liberal administration is complex. Three Bills were planned; one to deal with the denominational issues of concern to the Liberals, together with clauses dealing with educational trusts; a second, Consolidation Bill to codify the first Bill and other educational legislation; and a third Bill dealing with miscellaneous matters. Only the first two of these were published. The third first appears as Section III of the main Education Bill from draft 100/10, $19 \mathrm{March}$ 1906. Ibid. See Morant's proposals in PRO Ed24/118, memorandum by Morant, 23 February 1906.

${ }^{15}$ PRO Ed24/117, draft 100/14, cl. 15(b), 30 March 1906.
} 
within the power of "attending to the health and physical condition of the children". The new phraseology was retained, with only minor alteration, in the first published version of the 1906 Bill. ${ }^{16}$

Harold Tennant's amendment to the 1906 Bill, proposing that medical inspection be made compulsory, also followed this format:

It shall be the duty of every local education authority to make arrangements, in accordance with a scheme to be made by the Board of Education, for attending to the health and physical condition of the children in public elementary schools. ${ }^{17}$

Thus, although it has been suggested that the inclusion of the phrase "attending to the health and physical condition of the children" in the 1907 Act was the key to the establishment of medical treatment under the School Medical Service, ${ }^{18}$ it would seem that this phrase was originally intended both to sanction medical inspection and to allow other LEA activities, such as the employment of nurses to examine children for vermin, the legality of which were at the time subject to query. ${ }^{19}$ Only with the Government's response to Tennant's amendment were the two concepts separated, making it

The duty [of an LEA] to provide for the medical inspection of children before or at the time of admission to public elementary school, and on such other occasions as the Board of Education may direct, and [giving] the power to make such arrangements as may be sanctioned by the Board of Education for attending to the health and physical condition of the children educated in public elementary schools. ${ }^{20}$

Separation was now necessary to distinguish between the duty of medical inspection imposed on LEAs, and their power to undertake other work in the field of school health.

It can be argued that the original choice of the phrase in draft 100/14 was a result of decision by the Board to conceal the true extent of the work envisaged for the embryo School Medical Service, but this seems unlikely. At that time, in early 1906, Morant had no desire to develop a medical service at the Board. He did not disagree with the medical inspection or treatment of schoolchildren, but at this time his friend Mrs Beatrice Webb was trying to persuade the Royal Commission on the Poor Laws to recommend concentration of all health functions under the Medical Officer of Health locally and the Local Government Board (in the absence of an independent ministry of Health) centrally. Morant agreed with the basic principle of functional administration involved and the strengthening of preventive medicine which would ensue, and was thus unwilling to initiate any proposals which would jeopardize the achievement of this

${ }^{16}$ Education (England and Wales) Bill, as introduced, [Bill 160], cl. 35(b). BPP 1906, i.

${ }^{17}$ PRO Ed24/117, undated memorandum on proposed amendments to cl. 35 of the Education (England and Wales) Bill. Note that Gilbert's account implies that Tennant's amendment was the first mention of medical inspection in the 1906 Bill. Gilbert, op. cit., note 3 above, p. 127.

18 Ibid., p. 130. 1905.

${ }^{19}$ See, e.g., PRO Ed111/13, file on proposed appointment of a school nurse at Cambridge, 7 February

${ }^{20}$ Education [England and Wales] Bill, as amended in Committee and on Report [Bill 327], cl. 24(b). BPP 1906 , i. 


\section{J. David Hirst}

objective. ${ }^{21}$ For this reason, he was opposed in principle to the medical supervision of schoolchildren being the responsibility of educational bodies, believing it to be properly the responsibility of the Local Government Board. He had advanced this argument as early as $1903 .^{22}$

While the Balfour government was in office, the potential cost to the rates was sufficient to prevent any action, despite the enthusiasm of Sir William Anson, the Parliamentary Secretary to the Board. ${ }^{23}$ The political pressures generated by the more radical Parliament of 1906, and the continuing reluctance of the Local Government Board to take an initiative on school health were to force Morant's hand. The support for Tennant's amendment made it obvious that the Board of Education would have to act on school health.

In this situation, Morant's first concern was how best to prevent the ideal of a unified public medical service from being damaged irreparably by the now politically inevitable creation of a school health service. After explaining, almost apologetically, to a doubting Mrs Webb the political necessity of reintroducing the clauses giving medical powers to the LEAs, ${ }^{24}$ Morant moved to secure his objective. Rival candidates for appointment as Chief Medical Officer to the Board were rejected or ignored, ${ }^{25}$ in favour of a serving Medical Officer of Health, George Newman, a protégé of Sidney and Beatrice Webb, whose manoeuvres had helped secure the appointment for him. ${ }^{26}$ Morant's attempts to secure some integration between school health and public health administration were not universally popular either on principle, or among the supporters of the disappointed rivals for the appointment as Chief Medical Officer. ${ }^{27}$ But Newman's appointment was welcomed as maintaining the promise of eventual unification of public health services, while the School Medical Service itself represented a further advance for preventive medicine. Through medical inspection, doctors were now moving "from seeking to control the sick person and his family ambience to claiming to set standards for the whole society". ${ }^{28}$

While Morant was arranging for a suitable candidate to be appointed as Chief Medical Officer, the issue of medical treatment was being clarified in Parliament. This had received only cursory consideration during the 1906 debates, but in 1907 members could consider the issue during debates on two Bills. While the Government Bill was

\footnotetext{
${ }^{21}$ See Beatrice Webb, Our partnership, ed. Barbara Drake and Margaret I. Cole, London, London School of Economics and Cambridge University Press, 1975, pp. 316-42. Morant and Mrs Webb later served together on the (Haldane) Committee on the Machinery of Government, which proposed a general re-organization of Departments on functional lines in 1918. See Report of the Machinery of Government Committee of the Ministry of Reconstruction, Cd. 9230. BPP 1918, xii.

${ }_{22}$ PRO Ed23/198, draft letter to Royal Institute of Public Health by W. S. Davies, approved by Morant, (July 1903).

${ }^{23}$ See BM, Balfour Papers, Add. MSS 49787, f. 123, Morant to Balfour, 3 December 1904.

24 BLPES, Passfield Papers, Diary of Beatrice Webb, vol. 26, p. 57, 27 April 1907.

${ }^{25}$ See Gilbert, op. cit., note 3 above, pp. 133-6, although this contains some inaccuracies. Alfred Eich holz was an HMI with the Board at the time. J. D. Hirst, 'A failure without parallel: the School Medical Service and the London County Council, 1907-1912', Med. Hist., 1981, 25: 281-300.

${ }_{26}^{26}$ See BLPES, Passfield Papers, II 4, n, 263, Newman to Lord Passfield [Sidney Webb], 1 June 1943.

27 See, e.g., The Times, 18 June 1907, p. 14; Br. med. J., 1907, ii: 760-1, 772-3.

28 F. B. Smith, The people's health, 1830-1910, London, Croom Helm, 1979. For the development of public health see also Jeanne L. Brand, Doctors and the state, Baltimore, Johns Hopkins, 1965; Dorothy E. Watkins, 'The English revolution in social medicine, 1889-1911', Ph.D. thesis, University of London, 1984.
} 
delayed by the negotiations with the Unionists, an impatient Liberal backbencher, Walter Russell Rea, introduced a private member's Bill dealing only with school health and vacation schools. Like that eventually introduced by the Government, this Bill incorporated verbatim the final version of the clause in the 1906 Bill permitting medical inspection. ${ }^{29}$ Far from concealing its intentions, Rea's Bill specifically declared itself to be one providing for the "medical inspection and treatment" of schoolchildren. ${ }^{30}$ In debates on both Bills it was acknowledged that treatment would be sanctioned if the clause was accepted. In the Committee stage of the Government's 1907 Bill, the Parliamentary Secretary to the Board, Thomas Lough, was reported to have suggested that medical treatment for minor ailments would be given "in a small hospital outside the school", 31 while, when introducing the same Bill in the Lords, the Earl of Crewe emphasized that

Provision is made for the medical care of the minor ailments to which children are subject, and the manner in which it is thought that this can best be carried out is by visits of nurses employed by the local authority to the homes of the children. ${ }^{32}$

The intention to introduce treatment provoked little opposition. The real issue was who should be responsible for the cost of any treatment provided.

This was an issue on which Morant showed caution, warning his Minister about discussing too openly the prospect of treatment being given "gratis". ${ }^{33}$ During debates on Rea's Bill a number of speakers demanded parental contributions towards the cost of treatment, ${ }^{34}$ but attempts to enforce a charge on parents were defeated by substantial majorities, during discussion of both Rea's Bill ${ }^{35}$ and that of the Government. ${ }^{36}$ Rea's Bill was eventually withdrawn in favour of that of the Government, which became law with the medical inspection clause almost unchanged from that of the 1906 Bill.

Morant could justifiably claim to have determined many aspects of the nascent School Medical Service; frequently, as with the appointment of Newman and the implicit affirmation of the links between school health and public health, he was imposing his own policy on the Board and on Parliament. But the power, if not yet the duty, to provide treatment was the subject of a broader consensus than he implied. Treatment was expected to take place, provided that the defects treated were related in some ways to the needs of the child at school. ${ }^{37}$ Not until after the First World War was this limitation seriously challenged either as a policy or as a practice. ${ }^{38}$

${ }^{29}$ As Rea stressed at the time: see Hansard, 4th series, 170: 426.

${ }^{30}$ Education Acts Amendment Bill, as introduced [Bill 22]. BPP 1907, i. Professor Gilbert is mistaken in suggesting that Rea's Bill "would have excluded any provision for treatment". Gilbert, op. cit., note 3 above, p. 129.

31 Hansard, 4th series, 180: 916, 920.

32 Ibid., 181: 726.

33 PRO Ed31/151, Morant to McKenna, 30 April 1907.

34 Hansard, 4th series, 176: 41, 45.

35 Ibid., 176: 57.

36 Ibid., 180: 926.

${ }^{37}$ Newman argued that as treatment was being performed under an Education Act, it should bear some relation to educational needs. PRO Ed50/7, memorandum by Newman, 29 June 1908.

${ }^{38}$ See PRO Ed50/45, minute papers on medical treatment, 1919. 


\section{J. David Hirst}

THE DEVELOPMENT OF TREATMENT

But if there was Parliamentary approval for treatment, what factors persuaded the LEAs to exercise their optional power to provide treatment facilities? The Annual Reports of the Chief Medical Officer indicate a steady increase in the number of councils offering treatment; school clinics, usually provided and controlled by the education authorities themselves, became the most favoured agencies for treatment provision.

The reasons for the growth in treatment and the pattern of provision that emerged merit inquiry, for these developments were by no means inevitable, particularly in view of the delicate relations between central and local government regarding the School Medical Service in its early years.

The Government desired a general reform of the education grant system, which was regarded as outmoded, over-complex, and inequitable. ${ }^{39}$ Rather than pre-empt funds required for this general reform, the Government failed to provide grant-in-aid for the School Medical Service when compulsory medical inspection commenced. As a result, the cost of the School Medical Service fell entirely on the LEAs, contributing marginally, but symbolically, to a continuing shift in the balance of education funding away from central government and on to the local rates, as the table below demonstrates.

FUNDING OF ELEMENTARY EDUCATION $\mathbf{4 0}^{\mathbf{4 0}}$
$\begin{array}{lllll}\text { Year } & \text { Exchequer grant (£) } & \text { Grant (\%) } & \text { Local rates (£) } & \text { Rates (\%) } \\ 1905-06 & 10,780,242 & 53.9 & 9,229,509 & 46.1 \\ 1906-07 & 11,380,781 & 54.5 & 9,491,704 & 45.5 \\ 1907-08 & 11,104,301 & 51.5 & 10,467,807 & 48.5 \\ 1908-09 & 11,329,380 & 50.7 & 11,012,390 & 49.3 \\ 1909-10 & 11,445,055 & 49.5 & 11,660,692 & 50.5 \\ 1910-11 & 11,530,132 & 48.7 & 12,129,796 & 51.3 \\ 1911-12 & 11,735,441 & 48.2 & 12,593,765 & 51.8\end{array}$

(Total expenditure on the SMS in 1911-12 was $£ 197,128$.

This trend was resented by the LEAs, who launched a vigorous, but for some years unsuccessful campaign to obtain grant aid for medical inspection. ${ }^{41}$

The lack of financial support from the central government meant that there was no direct monetary incentive for an LEA to exercise its optional power to provide treatment. At most, the Board of Education could exhort LEAs to consider providing treatment. The Board's attitude was signalled in a series of circulars issued between November 1907 and August 1908, touching on various aspects of the new service. The pre-publication drafts of the first of these, Circular 576, are interesting in providing evidence of George Newman's opinions at a time when he was relatively isolated from the Board of Education, not yet operating from the Board's offices, but working out

\footnotetext{
${ }^{39}$ For a contemporary analysis of the inequities of the existing education grant system, see Sidney Webb, Grant-in-aid: a criticism and a proposal, London, Longmans Green, 1911.

${ }^{40}$ Final Report of the Departmental Committee on Local Taxation, Cd. 7315, p. 26. BPP 1914, xl.

${ }^{41}$ See Hirst, op. cit., note 25 above, pp. 286-7.
} 
his notice as Medical Officer of Health for Finsbury. He was not to begin his work at the Board until 9 December $1907,{ }^{42}$ although he was constantly in touch with Morant by letter.

Newman's long career in public health was to bring him many honcurs and distinctions, which he meticulously recorded in his diary. At times, the praise of contemporaries was hyperbolic in the extreme. ${ }^{43}$ Recent scholarship has been more critical of Newman's record ${ }^{44}$ and his views about medical treatment by local authorities seem at this juncture to be more conservative than innovatory. In his first rough notes he thought treatment was "not to be undertaken by [a] Local Authority except [for] minor [ailments?]". 45 The first full draft continued this approach, observing that

speaking generally Local Education Authorities should not undertake direct medical treatment. There can be no doubt that a system of treatment, or as it would soon become, medical relief administered by the Education Committee might tend to pauperise the patient. [Therefore] . . . the Board look to the existing agencies of the medical profession for treatment of the defects revealed by inspection under this Act, ... [including] ... private medical practitioners ... [and] ... dispensaries and hospitals. ${ }^{46}$

This view is reminiscent of the Charity Organisation Society, and was certainly not designed to encourage an LEA to provide treatment independently.

A more positive emphasis came only after Morant had shown the draft to some of his contacts outside the Board, and to Reginald McKenna, the President of the Board of Education. It was then suggested to Newman that the circular should

put more peremptorily the duty [sic] to treat the minor ailments, e.g. ringworm, dirty heads, etc., [and] to speak of other and more comprehensive treatment as a matter for which proposals will be submitted to us by Local Authorities later on. ${ }^{47}$

The Circular itself therefore avoided the discouragement of LEA treatment in the earlier drafts, and noted

that L.E.A.'s should keep in view the desirability of ultimately formulating and submitting to the Board . . . schemes for the amelioration of the evils revealed by medical inspection, including, in centres where it appears desirable, the establishment of school surgeries or clinics.

But it warned that "speaking generally, [authorities] will be unable to formulate ... any comprehensive scheme . . . until they have considered the results of their medical inspection". 48

${ }^{42}$ DHSS, Newman Diaries, vol. 1, 9 December 1907.

${ }^{43}$ For example his description, allegedly by Lord Liddell, as "the greatest hygienist since Moses": Times educ. Suppl., 29 May 1948.

${ }^{44}$ See, e.g., Charles Webster, 'Healthy or hungry thirties', Hist. Workshop J., 1982, 13: 110-29.

45 PRO Ed50/5, rough notes for Circular 576, undated.

46 Ibid., Circular 576, first written draft.

${ }^{47}$ PRO Ed24/280, Morant to Newman, 15 November 1907. Margaret McMillan was one of those consulted. Gilbert, op. cit., note 3 above, p. 138.

${ }^{48}$ Board of Education, Circular 576, 1907, para. 14. 


\title{
J. David Hirst
}

Although the Circular thus suggested that treatment schemes would be favourably considered after experience of inspection, it is possible that this was more than Newman desired. Six months later he was again arguing that the

\begin{abstract}
Primary duty of the state is to point out defects and disease and ... to leave treatment as far as possible to the ordinary channels and therapeutics and particularly to those channels which increase rather than decrease the sense of responsibility in the parents and guardians of the children. ${ }^{49}$
\end{abstract}

The role of LEA clinics should therefore be limited to conditions for which no other agency was able to provide suitable and adequate treatment. Where the choice was finely balanced, as with dental treatment, or the treatment of tonsils and adenoids, then Newman believed:

On the whole I think we must press hospital treatment as far as possible, and where this is impossible we must allow these things to be included among those conditions suitable for treatment at a School Clinic. ${ }^{50}$

Under Newman's guidance, the Board was adopting a cautious approach to treatment by the LEAs. Consideration before implementation, and the use of existing agencies where possible, were the apparent bases of policy. In August 1908, the Board again issued public guidance on treatment in Circular 596. In this, the Board suggested that treatment provision should be seen as a hierarchical progression, and the Circular aimed "to indicate the order in which, in the Board's opinion, it is desirable that the Local Education Authority should consider the various methods ... open to them" for providing treatment. Eight options were then listed. The first four of these proposals were simple matters of improved administrative co-operation or more effective use of existing powers: improving school premises, expanding special education, cooperating with the sanitary authority, and giving advice to parents. Some additional expenditure might be incurred with the fifth and sixth of Newman's suggestions, the employment of school nurses and the provision of spectacles, but only the last two proposals, contributions to hospitals and dispensaries in exchange for treatment, and the foundation of school clinics, were schemes which comprehensively extended the activities of LEAs in relation to medical treatment.

Treatment in a clinic would, it was claimed, "give rise . . . to questions of considerable difficulty" and before sanction was given the Board would want to satisfy itself "that full use has been made of the ordinary and less ambitious means available". LEAs would have to tell the Board:

\footnotetext{
What precautions ... [they] . . will take to secure that only those children shall be treated in a School Clinic for whose treatment adequate provision cannot otherwise be made, whether by the parents or by voluntary associations or institutions, or hospitals, or through the agency of the Poor Law. ${ }^{51}$
}

\footnotetext{
49 PRO Ed50/7, memorandum by Newman, 29 June 1908.

${ }^{50}$ Ibid.

${ }^{51}$ Board of Education, Circular 596, 1908, para. 7.
} 
In the early months of the School Medical Service, some authorities were actively discouraged from establishing school clinics. The Principal Assistant Secretary to the Board, L. A. Selby-Bigge, noted that

Dr. Newman and I have, in several cases where Local Education Authorities showed signs of going in for expensive forms of treatment, advised them to proceed in the first instance by subsidising hospitals. ${ }^{52}$

Nor did the Board evangelize, preferring LEAs to take the initiative rather than overtly encouraging the provision of treatment. At the outset, the development of treatment facilities was stimulated by the actions of local authorities, rather than the central department. But here the Board's passivity can be explained by embarrassment at the lack of grant-in-aid, and its desire not to provoke further anger on the part of local government by pressing for the expansion of a service for which it provided no financial support.

The growth of treatment in general, and the increasing use of school clinics in particular, therefore owed much to pressures within and upon each individual LEA, at least until the Board later adopted a more positive and active policy to support the development of treatment. Although Morant did not require the statistics of defective children to persuade Parliament to assent to treatment, revelations about the condition of children in LEA areas undoubtedly aroused local concern. But more potent than the simple revelations of defect was the disappointment subsequently expressed about the allegedly low percentage of parents who took action once their child's ailment had been pointed out to them. Many of the early Annual Reports of School Medical Officers dwelt at length on this problem and its cause. Sometimes parental ignorance or neglect were blamed. But other School Medical Officers recognized the real problem as the unavailability, inaccessibility, or unsuitability of existing avenues of treatment. The general practitioner was too expensive for many parents to contemplate, and the Poor Law was tainted. ${ }^{53}$ Where possible, many parents took their children to the out-patient departments of the local voluntary hospitals, and an increase in the numbers attending was noted in many areas. ${ }^{54}$ Sometimes, this was actively encouraged by the education authority in the notification sent to parents. ${ }^{55}$

Referring children to the voluntary hospitals had been a standard practice of education committees since vision-testing programmes of the 1890 s and early $1900 \mathrm{~s}$. It had then been vigorously opposed by many hospital staff. ${ }^{56}$ Now, similar protests ensued from hospitals throughout the country. Many hospitals refused to treat schoolchildren, ${ }^{57}$ while others called on the LEAs to take action to control the

\footnotetext{
52 PRO Ed125/11, Precedent Cover: West Sussex, July 1908.

53 See e.g. Lancet, 1908, ii: 191, 1560; 1909, i: 437; 1910, i: 1513; Publ. Hlth, Lond. 1908-9, 22 : 463.

54 Board of Education, Annual Report of the Chief Medical Officer for 1908, Cd. 4986, p. 34. BPP 1910,

55 See, e.g., Felling U.D.C., Annual Report of the School Medical Officer for 1908, p. 4.

56 See J. D. Hirst, 'Vision testing in London: a rehearsal for the School Medical Service', J. educ. Admin \& Hist., 1983, 14(2): 23-9.

${ }^{57}$ See, e.g., Lewis D. Cruickshank, School clinics: at home and abroad, London, National League for Physical Education and Improvement, 1913, p. 40; Arthur Newsholme, International studies on the relation
} xxiii. 


\section{J. David Hirst}

numbers of children flooding to the out-patient departments. ${ }^{58}$ The alleged "abuse" of charitable medical facilities was an issue of some concern at the time, and the hospital authorities considered that the parents of many of the children referred to them were well able to pay for treatment. ${ }^{59}$ Their staff meanwhile complained of the disruption to departmental routine caused by the arrival of large numbers of schoolchildren, and the monotonous and medically uninteresting nature of the children's complaints. ${ }^{60}$

For parents also, there were often problems in using the hospitals. In some areas, the nearest hospital was many miles distant. Even where geographical access was easy, there were other difficulties: the prospect of investigation by the hospital almoner, intent on ensuring that only the "necessitous poor" received free treatment, or the need to obtain a subscriber's letter, created barriers which some parents were unable or unwilling to scale. The search for a subscriber's letter sometimes meant that "a great deal of begging and tramping is too often the necessary preliminary to treatment". ${ }^{2}$ Even where these barriers were surmounted, further problems remained. Hospitals would not treat unaccompanied children, so attendance at an out-patient department would entail loss of earnings for the parents and travelling expenses. ${ }^{62}$ The over-crowding in the waiting areas made it uncertain whether treatment would be obtained at all, especially when the harassed and sometimes angry medical staff were restricting the numbers of children seen. ${ }^{63}$ The frequent need for two or more visits before the completion of treatment ${ }^{64}$ and the needlessly expensive and inappropriate remedies prescribed, especially for defective eyesight, ${ }^{65}$ meant that treatment, even when commenced, was frequently never completed.

The figures demonstrating the low rate of treatment obtained after medical inspection served as a spur to action by some LEAs, and, where the education committee itself was unwilling to act, as an incentive to a variety of other interests to press for action. Some of these interests were explicitly political: many councils received petitions and deputations from various socialist groups and trade union bodies urging that they should provide treatment. ${ }^{66}$ They were sometimes pressed by a second interested group, their professional staff, alarmed by the evidence of disease and ill-health discovered by the surveys, and also frustrated and demoralized by the low percentage of children obtaining treatment. ${ }^{67}$

between the private and the public practice of medicine, 3 vols., London, George Allen \& Unwin, 1931, vol. 3, pp. 367-76; Lancet, 1910, ii: 1728-9.

${ }_{58}$ Lancet, 1912, i: 1499.

${ }^{59}$ See London County Council (LCC), Education Committee, Minutes, 26 June 1907.

${ }^{60}$ See Hirst, op. cit., note 56 above.

${ }^{61} \mathrm{M}$. Cecile Matheson, The medical inspection of school children and after, Birmingham, Cornish Bros, 1910 , p. 8.

${ }^{62}$ See, e.g., Marion Phillips, The school doctor and the home, London, Women's Labour League, [1911], p. 2.

${ }_{63}^{6}$ See LCC, Education Committee, Agenda, 9 December 1908.

${ }^{64} \mathrm{Br}$. med. J., 1903, i: 616

${ }^{65}$ Inter-Departmental Committee on the Medical Inspection and Feeding of Children Attending Elementary Schools, vol. 2, Evidence and Appendices, Cd. 2784, p. 129, qu. 3833. BPP 1906, xlvii.

${ }^{66}$ See, e.g., Edmonton U.D.C., Annual Report of the School Medical Officer for 1912, p. 163; Bruce Castle Museum, Tottenham Education Committee, Minutes, 13 March 1911.

${ }^{67}$ Lancet, 1913, ii: 1504. 
The pressures on the LEA were not only generated by concern for the children. One consequence of medical inspection was the identification of children who were unfit to attend school. When action followed, the resulting absences could result in a loss of grant and consequent friction between medical officer and education committee. In Carmarthenshire, one councillor complained that "for hundreds of years the children had been taught in a dirty condition" without complaint, until the school medical officer had barred some verminous children from school. ${ }^{68}$ In the case of some ailments, the financial loss to the council could be significant. Ringworm, treated conventionally, required prolonged and systematic application of ointments to the scalp. To avoid spreading the infection, most authorities excluded infected children from school, except where sufficient numbers existed for special "ringworm classes" to be established. But the difficulties of conventional treatment meant that some children were absent for prolonged periods. In Shropshire, the School Medical Officer's Annual Report for 1915 commented that "three children have been absent from school off and on for more than six years, five for five years, ten for four years, seventeen for three years, and thirty two for two years, on account of ringworm". ${ }^{69}$

Such prolonged absences lost the LEA capitation fees, quite apart from the effects on the education of the individual child. The interest shown by some LEAs in the treatment of ringworm by X-rays thus had economic, rather than purely humanitarian motives. ${ }^{70}$ This technique, though expensive, could effect a cure within weeks, and thus more than repaid the cost to the authority.

Driven by this combination of political, humanitarian, and economic considerations, a growing number of LEAs took action to increase the proportion of defects receiving treatment. The eight options in Circular 596 by no means exhausted the possibilities. Some councils adopted a coercive approach, particularly with verminous children, and, sometimes, ringworm cases. Children so afflicted would be excluded from school and action taken against the parents under the School Attendance Acts if they were not cured within a reasonable period. ${ }^{71}$ Other councils rejected the idea of direct LEA provision of treatment and attempted to encourage the growth of voluntary provident medical societies and clubs for school children. The idea was considered by the London County Council (LCC), but rejected. ${ }^{72}$ Provident schemes were tried in Norfolk, West Sussex, Cumberland, and Carnarvonshire, ${ }^{73}$ but the most extensive and sustained attempt to establish a provident medical club was made in Derbyshire, where the County Medical Officer of Health, Sydney Barwise, was a committed supporter of the concept. Ambitious proposals for a county-wide

\footnotetext{
68 Ibid., 1912, i: 59.

${ }^{69}$ Shropshire CC, Annual Report of the School Medical Officer for 1915, p. 11.

${ }^{70}$ Ibid. A description and recommendation of the use of X-rays to treat ringworm may be found in Board of Education, Annual Report of the Chief Medical Officer for 1912, Cd. 7184, pp. 158-9. BPP 1914, xxv. Another author admitted that at first "a number of regrettable incidents took place" while using the technique, as it was difficult to estimate the correct dosage, although "if a dose 10 per cent too great is given the hair never grows again". This, not surprisingly, was said to have led to parental opposition to X-ray treatment. See Haldin Davis, 'X-ray treatment of Ringworm', The Child, 1911-12, 2: 511-12.

${ }^{71}$ See Board of Education, Annual Report of the Chief Medical Officer for 1909, Cd. 5426, pp. $198-202$. BPP 1910, xxiii.

72 LCC, Education Committee, Agenda, 9 December 1908.

${ }^{73}$ Med. Offr, 1910, 3: 304; PRO Ed 125/8, Precedent Cover: Carnarvonshire.
} 


\section{J. David Hirst}

scheme, with 90 per cent of the children in the county's schools expected to pay $2 d$. per quarter, were postponed when only 40 per cent of parents proved willing to contribute. ${ }^{74}$ Barwise persisted with a pilot scheme in the Clay Cross area, but this foundered on the opposition of local GPs. ${ }^{75}$

Most LEAs limited their options to those specified in Circular 596 in a gradually ascending order of comprehensiveness and expense. Despite the deliberate progression of the options in the circular, and Newman's evident reservations about treatment provision by the LEAs themselves, even in the earliest years of the School Medical Service some authorities succeeded in gaining permission from the Board to establish school clinics, and the number choosing to provide treatment by this means increased both absolutely and as a proportion of all authorities giving treatment in later years, as the comparative table below indicates:

LOCAL AUTHORITIES PROVIDING MEDICAL TREATMENT ${ }^{76}$

$\begin{array}{llccc}\text { Year } & \text { Some provision } & \text { Clinics } & \text { Hospital treatment } & \text { Free spectacles } \\ 1908 & 55 & 7 & 8 & 24 \\ 1914 & 266 & 179 & 75 & 165 \\ 1917 & 279 & 231 & 95 & 223 \\ 1920 & 309 & 288 & 168 & 282\end{array}$

(During this period the total number of LEAs varied between 328 and 317.)

THE RISE OF THE SCHOOL CLINIC

Two questions arise. Why did the Board allow some councils to establish school clinics at such an early date, bearing in mind that the Board was opposed to the establishment of clinics in principle? Why did the clinic increasingly become the dominant mode of provision, gaining preference over the use of the existing hospitals?

The first question can be partly answered by reference to the differing experience of LEAs prior to the 1907 Act. Most councils had never previously performed medical inspection, but a minority had some experience of medical supervision, extending in some instances to attempts to provide, organize, or obtain medical treatment for the children concerned. In rare instances, these were arrangements of long standing. London had first appointed a medical officer in 1890, Bradford in 1893. Following the Elementary Education (Defective and Epileptic Children) Act of 1899, other school boards did the same. ${ }^{77}$ Where medical inspection had taken place prior to 1907, efforts were usually made to ensure that treatment was obtained, mainly by urging parents to go to the voluntary hospitals or other sources of medical advice. ${ }^{78}$

This experience allowed some authorities to argue that they had already discovered the problems of relying on existing treatment agencies, and had the proficiency to organize their own schemes efficiently. A school clinic for Bradford was in fact the

${ }^{74}$ Sch. Hyg., 1910, 1: 247.

75 Lancet, 1911 , i: 514.

${ }^{76}$ The figures in this table are collated from the various Annual Reports of the Chief Medical Officer to the Board of Education.

${ }^{77}$ For details of appointments see Medical Inspection and Feeding Committee, op. cit., note 65 above, Appendix 5, pp. 235ff.

${ }^{78}$ See Hirst, op. cit., note 56 above. 
second scheme of treatment to be sanctioned by the Board. As part of its submission requesting permission for the clinic (which was already operational), Bradford stressed that its long experience of medical work had shown that the out-patient departments of the local hospitals could not cope with the demand from schoolchildren. ${ }^{79}$

Although Bradford's achievements in the field of school health and nutrition were widely known, Newman visited the city before making a decision. Local councillors and the School Medical Officer, Ralph Crowley, a fellow Quaker and a personal friend of Newman since $1895,{ }^{80}$ agreed that only children specifically referred by the LEA should be sent to the clinic. Children getting treatment by other means, or brought unilaterally to the clinic by their parents, were to be excluded. With these conditions agreed, the Board assented to Bradford's scheme. L. A. Selby-Bigge thought it "the kind of temperate proposal which we should favour". ${ }^{81}$

For may LEAs the lack of Government grant-in-aid was a powerful disincentive to the provision of treatment of any kind, and only the continuation of the problem of low rates of treatment eventually persuaded many councils to take action.

Authorities deciding to make their own arrangements for treatment were faced with a choice between hospital treatment and school clinics. Although virtually unknown in Britain before 1907, it was the school clinic which was to become the preferred mode of provision. This resulted from a combination of the problems experienced with the hospital treatment system, professional and political pressure, and administrative and educational convenience.

From the LEAs' viewpoint there were many advantages in making an agreement with a local voluntary hospital to provide treatment. It would avoid the anarchic chaos which resulted from simply suggesting to parents that they took their children to the out-patient department; it would use an existing, usually long established, and well regarded institution; and it gave direct access to the medical expertise, equipment, and facilities available. For some councils, using a voluntary, nonmunicipalized service had ideological attractions also.

But there were also countervailing pressures against the use of the voluntary hospitals, not least from the various professional interests; the hospitals' staff and, representing a wider spectrum of medical opinion, the British Medical Association. The hospitals' staffs' reluctance to treat schoolchildren stemmed largely from the experiences of some of their number in dealing with children referred by the LEAs (and school boards previously) in the period before 1907. They were supported by the BMA, concerned not only for its members in the hospital service, but also to protect the interests of the general practitioners, who saw a threat to their livelihood from the "abuse" of hospital facilities. ${ }^{82}$

The anger of the hospital doctors and the anxieties of the GPs thus combined to create a climate of professional opinion that was antagonistic to the use of hospital

\footnotetext{
${ }^{79}$ PRO ED125/8, Precedent Cover: Bradford, October 1908.

${ }^{80}$ HWCRO, Newman Papers, M4/168, Notes from Newman's papers by Evelyn S. Whiting, for a proposed biography.

${ }^{81}$ Board of Education, op. cit., note 54 above, p. 99; PRO Ed125/8, op. cit., note 79 above.

${ }^{82}$ See Gilbert, op. cit., note 3 above, pp. 148-54.
} 


\section{J. David Hirst}

facilities by schoolchildren in the way commonly practised: the unregulated referral of children to the out-patient departments by LEAs. This, and perhaps also the personal preferences of James Kerr, London's School Medical Officer and one of the members of the sub-committee formulating the policy, led the Medico-Political Committee of the BMA to propose that school clinics were to be preferred as a means of treatment for schoolchildren. To safeguard the interests of local GPs, it was suggested that they should staff the clinics rather than the medical officers of the education committee. ${ }^{83}$ The BMA's support for school clinics may have reduced the opposition from existing medical interests which might otherwise have met the creation of new institutions.

In practice, the doctors were less united in their opposition to the use of hospitals than BMA policy suggests. In part this was because the LEAs were able to use their powers under the new Act to negotiate agreements which, by ending the practice of unilateral and unrestricted referral of children to the out-patient departments, eliminated many of the objections of both hospital managers and medical staff. This left the GPs, who were themselves divided on the issue, isolated in their opposition to hospital treatment of schoolchildren.

LEAs could formalize their use of the hospitals in a number of ways. Simplest was to become a subscriber to the hospital, receiving tickets which could be given to children needing treatment. Although convenient for the authority, this did nothing to alleviate the problems of the parents who had still to brave the out-patient waiting rooms. The hospital staff sometimes objected strongly to this arrangement, claiming that it took advantage of their goodwill. In some areas, medical opposition thwarted plans to subscribe to the hospitals. ${ }^{84}$ Conversely, other councils were able to subscribe for "letters of recommendation" without hindrance for virtually the whole period prior to the First World War. ${ }^{85}$ Alternatively, the LEA could contract with the hospitals to treat schoolchildren at specified times. This had mutual advantages. For the hospitals, it kept the children out of the out-patient departments at the normal times or, at least, restricted their numbers to those agreed. For the LEAs, it gave a greater probability that the children would be seen and attended. Sometimes, the hospitals were driven to seek these arrangements by the pressure of children disrupting their normal routine. In Bristol, the council agreed with local hospitals to treat cases referred by the schools. The education committee was to restrict the numbers referred and "maintain order". 86

The LCC made greatest use of agency agreements with the voluntary hospitals. ${ }^{87}$ Since 1907, the LCC had been controlled by the Moderate (i.e. Conservative-aligned) Party, opposed to the growth of municipal enterprise and expenditure. Although recognizing that children had to receive treatment, the Moderates' ideological preference was to act through the voluntary hospitals. The LCC's Education Officer, Robert Blair, was therefore instructed to seek agreements with several voluntary hospitals for the treatment of children referred by the medical staff of the Council's Education Department.

${ }^{83}$ Br. med. J., Suppl., 1908, ii: 42.

${ }^{84}$ Lancet, 1911, i: 1715; 1912, i: 1048.

${ }^{85}$ Shropshire CC Annual Report of the School Medical Officer for 1914, p. 42.

${ }^{86}$ Lancet, 1913, ii: 591.

${ }^{87}$ See Hirst, op. cit., note 25 above. 
The negotiations took some months. The governing bodies of the hospitals were concerned that the scheme would result in political interference or professional intervention by the LCC's own medical officers, while their staff worried about perpetuation of the chaos previously experienced. Periodic salvoes directed against the proposals appeared in the medical press. ${ }^{88}$ In fact, the agreement eventually concluded overcame many of the objections of doctors and governors. The LCC agreed to pay the additional salary and equipment costs of the hospitals, together with a capitation fee for children attending, whose numbers would be controlled by the LCC's own administration. ${ }^{89}$ The LCC's agreement formed a model for hospital treatment arrangements, and the Board of Education, although Newman was sceptical of the effectiveness of the scheme proposed, gave its sanction in December 1909. 90

The subsequent difficulties of the hospital treatment scheme in London indicate why school clinic provision found increasing favour with even the most fervent opponents of municipalization. The London scheme was undoubtedly affected by certain special problems unique to the capital: the distribution of the child population relative to the treatment centres, and the large number of hospitals in the capital which remained outside the scheme. Most of the hospitals with which the LCC reached agreement were long-established foundations in the centre of London, but many of the children needing treatment were living considerable distances away. For a child in the outlying borough of Woolwich, therefore, a visit to the designated hospital for treatment meant

a tedious and fatiguing journey for himself and his mother, or some other adult, of anything between one and two hours; usually a long period of waiting; very frequently, the discovery of some mistake or difficulty, so that no treatment is given; then the journey back again. If frequent visits are necessary, the expense becomes considerable. ${ }^{91}$

Other children in the centre of London, meanwhile, who might be living within yards of a hospital outside the treatment scheme, found themselves being sent considerable distances to another hospital. "St. Pancras people are taken past the Temperance and University College Hospitals to Charing Cross [Hospital]".92 Understandably, many parents tried to take their children to the nearest hospital, rather than that designated, especially as the treatment scheme incorporated a means test to determine the contribution the parent had to pay towards treatment costs. ${ }^{93}$

Although there were unique difficulties, the well-documented troubles of the London system also illustrate the generic problems of hospital treatment schemes for schoolchildren. Ideally, they assured treatment by limiting the numbers of children attending and removing them from the general mêlée of the out-patient departments.

${ }^{88}$ Lancet, 1909, i: 1484.

${ }^{89}$ LCC, Education Committee, Minutes, 3 November 1909.

90 PRO Ed125/9, Precedent Cover: London, 1 December 1909.

${ }^{91}$ Cruickshank, op. cit., note 57 above, p. 52.

92 LCC, Children's Care (Central) Sub-Committee, Agenda, 1 December 1910.

${ }^{93}$ GLRO, LCC File PH/SHS/2/4, Memorandum on medical treatment at Charing Cross Hospital, January 1910 . 


\section{J. David Hirst}

This ideal was not always fulfilled. The LEA's dependence on an independent body for treatment sometimes resulted in administrative muddles and confusion, with children being sent to hospital on days when the special consultations were not available. ${ }^{94}$

More serious were the deficiencies in the treatments provided and the care given to the children. Pressure on facilities when children were having tonsils and adenoids removed led to "cases where the children, after operation, have to be sent home by tramcar or omnibus in a condition unpleasant to themselves and to all who see them". ${ }^{95}$ At Charing Cross Hospital it was alleged that children were

Brought out of the operating room and laid on the floor of the ante-room in batches to recover consciousness, often with a considerable amount of blood on their garments, where they are seen by other children passing through to be operated on. ${ }^{96}$

Nor did the arrangements made by the authorities deal with many of the problems previously encountered with hospital treatment: the need for multiple visits and the prescription of inappropriate or needlessly expensive remedies. For some conditions where frequent, even daily attendance was required, hospital treatment was impossibly inconvenient.

Fundamentally, the central problem was the unwillingness or inability of hospitals and their staffs to modify their traditional procedures and concepts of treatment to suit the needs of schoolchildren and the LEAs. Although the arrangements with the LEA could separate the children from the normal crowds in the out-patient department, decisions about the timing of the treatment sessions and the date of the consultations were still made by, and arranged for the convenience of, the hospitals and their staff. Only rarely were exceptions to be found. At The London Hospital, children were treated in a purpose-built annexe. The London experienced high rates of attendance, though here the absence of competing institutions in the area of east London served by the hospital might have helped. At The London, as elsewhere, the hospital's charitable status created other difficulties. An LCC file is full of letters from the hospital's vigilant almoner detailing cases where the parents were considered able to pay for treatment. ${ }^{97}$ Some hospitals reconsidered their participation in the treatment scheme when their income from voluntary contributions diminished, allegedly because contributors objected to being charged for treatment for their children. ${ }^{98} \mathrm{~A}$ further consequence of the LCC's arrangements was the exclusion of children not covered by the scheme. Parents who took their children to hospital on their own initiative now found that they were refused treatment. ${ }^{99}$ Parents and children from outside the LCC area, who had previously made substantial use of the out-patient departments, also now found themselves excluded, though their own LEAs might not yet offer treatment. ${ }^{100}$

94 GLRO, LCC File PH/SHS/2/10, Medical Treatment at The London Hospital.

${ }^{95}$ Lancet, 1910, ii: 1437.

${ }^{96}$ GLRO, LCC File PH/SHS/2/5, Medical Treatment at Charing Cross Hospital. The Hospital Secretary responded that "it is true they are laid on the floor-a very safe place in my opinion ...". Ibid.

${ }^{7}$ GLRO, LCC File PH/SHS/2/10, op. cit., note 94 above.

${ }^{98}$ LCC, Children's Care (Central) Sub-Committee, Agenda, 27 January 1911.

99 Ibid., 1 December 1910.

${ }^{100}$ Cruickshank, op. cit., note 57 above, p. 40. 


\section{The School Medical Service 1908-18}

Hospital treatment of schoolchildren thus had many potential disadvantages, though some could be and sometimes were overcome. But other problems were unavoidable: the hospital was unsuitable for the treatment of certain complaints, and the hospitals' independence and charitable status created administrative difficulties. As medical treatment developed, an increasing number of LEAs used hospital treatment, but the associated difficulties meant it was to be the school clinic which was eventually to be the most popular form of treatment provision.

The campaign for school clinics has been inextricably associated with the work of the socialist and educational reformer, Margaret McMillan. But important though her work was, her direct contribution to the growth of the clinic system in Britain has been inflated by a capital-centred focus on events which ignores developments outside London. Miss McMillan hoped to persuade the LCC of the value of the school clinic system, and she obtained funds from Joseph Fels, the naphtha soap tycoon, for an experimental clinic at Devons Road School, Bow. For logistical reasons, attendance at this clinic was limited, and threatened to identify clinic treatment as costly and inefficient, so in March 1910 it was closed. ${ }^{101}$ A more successful replacement was opened in Deptford in June 1910. ${ }^{102}$ But by this juncture, municipal clinics were operating successfully in many areas, and Miss McMillan's clinic was significant only in the London context, as a visible contrast to the Moderates' hospital scheme.

The demand for better care for schoolchildren was always prominent in the socialist movements, and individuals besides Margaret McMillan made significant political or financial contributions. ${ }^{103}$ It is possible that the championship of the school clinic concept by socialist organizations may have made some councils reluctant to consider the idea. The clinic could be openly attacked as an example of wasteful "municipal socialism". 104

But support for the clinic was more broadly based. The admiration of German educational institutions inspired by the developing Imperial rivalry ${ }^{105}$ had its echoes among the medical profession. The over-pressure scare of the 1880s, one of the first manifestations of concern for the health of children at school, had links with the work of German physicians like Cohn and Treichler. ${ }^{106}$ Later, there was considerable interest in the remedial measures adopted by the German government, including, in the field of school health, the municipal clinics established in some German towns.

The Board of Education had published a report by W. H. Dawson on the German system of school doctors in $1906 .{ }^{107}$ George Newman referred to the systems of

${ }^{101}$ Margaret McMillan, The life of Rachel McMillan, London, J. M. Dent \& Sons, 1927, p. 118.

102 Idem, The school clinic today, London, Independent Labour Party, [1911], pp. $11 \mathrm{ff}$.

${ }^{103}$ See, e.g., Andro Linklater, An unhusbanded life: Charlotte Despard, London, Hutchinson, 1980, pp. 66, $71,99$.

104 The Times, 1 September 1908, p. 8.

${ }^{105}$ See W. H. G. Armytage, The German influence on English education, London, Routledge \& Kegan Paul, 1969.

${ }^{106}$ See A. B. Robertson, 'Children, teachers and society: the over-pressure controversy $1880-1886$ ', Br. J. educ. Stud., 1972, 20: 315-23; Hermann Cohn, The hygiene of the eye in school, trans. W. P. Turnbull, London, Simpkin Marshall \& Co., 1886; The Times, 8 April 1880, p. 7.

${ }^{107}$ W. H. Dawson, School doctors in Germany, Board of Education Educational Pamphlets No. 4, London, Wyman \& Sons for HMSO, 1906. 


\section{J. David Hirst}

medical inspection in Germany in 1907, before his appointment, and probably used them as a model for Circular 576. ${ }^{108}$ He later saw the German arrangements for himself. ${ }^{109}$ The German school clinics were enthusiastically publicized by the Prussophile Dr W. Leslie MacKenzie, a former pupil teacher who became Medical Officer to the Local Government Board for Scotland. ${ }^{110}$ The BMA's support also increased professional awareness of the clinic system as an alternative to hospital treatment, while wider publicity was given to the clinics in a long article in The Times in 1908. ${ }^{111}$

The first British clinic was a charitable, exclusively dental clinic in Cambridge in 1906, apparently a somewhat improvised affair where "a lady's drawing room is used for operations, and her garden acts as a waiting room". ${ }^{112}$ Other early clinics owed much to socialist and radical influences, as with Margaret McMillan's foundation at the Devons Road School, or the school clinic at Bradford, an authority with a long history of challenging the legal bounds of educational powers. ${ }^{113}$ But the subsequent expansion of the clinic system required a less partisan motivation.

The absence of any central government contribution to the costs of the School Medical Service initially restricted the expansion of all forms of treatment provision, but in the years immediately prior to the First World War the situation was alleviated by the provision of a grant. In 1912-13, this covered treatment costs only, and 69 authorities qualified for the maximum grant of 50 per cent, available for those with comprehensive treatment schemes, operating either through clinics or hospitals. ${ }^{114}$ In subsequent financial years, however, the grant was extended to cover the cost of all School Medical Service work. The restructured grant was intended to be "dynamic" and "directed to inducing local agencies to provide those additional facilities which at particular times seemed most necessary or desirable". ${ }^{115}$ Only authorities with comprehensive treatment schemes obtained the maximum 50 per cent grant. However, as a marginal increase in cost through the provision or expansion of treatment facilities led to an increase in the percentage of all the LEA's expenditure on the School Medical Service met from grant, additional spending on treatment could be more than recouped in the extra grant received. ${ }^{116}$ Some School Medical Officers were quick to point out the financial benefits which could now accrue from expanding provision for treatment. ${ }^{117}$ The number of LEAs with maximum grant increased consistently, even during the war years, which saw

\footnotetext{
${ }^{108}$ See George Newman, The health of the state, London, Headley Bros., 1907, p. 148.

${ }^{109}$ DHSS, Newman Diaries vol. 1, 10-25 March 1909.

${ }^{110}$ See, e.g., W. Leslie MacKenzie, The health of the school child, London, Methuen, 1906, pp. 12ff., 58ff.

111 The Times, 23 August 1908, p. 11.

112 Cruickshank, op. cit., note 57 above, pp. 130-1; See also Sch. Hyg., 1910, 1: 247.

113 See, e.g., David G. Pritchard, Education and the handicapped, 1760-1960, London, Routledge \& Kegan Paul, 1963, p. 128; Bradford Corporation, Educational Services Committee, Education in Bradford since 1870, Bradford, Bradford Corporation, 1970, p. 31.

114 Board of Education, Annual Report of the Chief Medical Officer for 1915, Cd. 8338, p. 23. BPP 1916,

${ }^{115}$ Sir Lewis Selby-Bigge, The Board of Education, London, G. P. Putnam's Sons, 1927, pp. 83-4.

116 PRO Ed50/63, Medical Department Procedure Minute M27, 30 June 1914.

117 See, e.g., Hampshire CC, Annual Report of the School Medical Officer for 1914, p. 4.
} viii. 
considerable disruption both to the School Medical Service and to other civilian medical services. By the 1917-18 financial year, 150 LEAs received maximum grant. ${ }^{118}$

With the financial climate now supportive of treatment schemes, the choice of clinics rather than hospitals was dependent on factors other than the largely socialist and radical commitments behind many of the original foundations. These were still present: within two or three years of the opening of the first clinics, several publications, largely from socialist and radical sources, were proclaiming their advantages, sometimes going beyond discussion of their effectiveness as diagnostic and remedial centres to making utopian claims about their contribution to the communal socialization of the children as future citizens. ${ }^{119}$ But clinics grew in numbers because of a wider recognition of their positive advantages, rather than simply a recognition of the disadvantages of the hospitals and other sources of treatment. The disadvantages, and sometimes the unavailability of hospital treatment were of course factors. In Brighton the school clinic was founded as a direct result of the local hospitals' refusal to allow the education committee to use "subscribers tickets" to obtain treatment for schoolchildren. ${ }^{120}$ The remoteness of the nearest voluntary hospital, seventeen miles away by train, led to the founding of the Abertillery school clinic by the borough Medical Officer of Health, Dr Remmett Weaver. ${ }^{121}$ Even before the Moderate administration of the LCC was fully ready to acknowledge the failings of their system of hospital treatment, the remoteness of some areas of the County from the nearest hospital in the scheme led to the use of "treatment centres" in some areas, of which the first was Norwood, essentially school clinics staffed by a panel of local GPs. ${ }^{122}$

But the clinic was now seen to possess positive advantages. It was administratively convenient to bring the treatment facilities under the control of the body responsible for medical inspection and the notification of defects to parents. This, it was argued, meant that the problems of "leakage" between inspection and treatment could be minimized, non-attendance for treatment more easily monitored, and inconvenience to parents and children reduced. ${ }^{123}$ The extent to which these advantages were realized in practice depended on the efficiency of the responsible LEA.

Purely as an avenue of treatment, the clinic was also claimed to have advantages over the hospitals and other institutions. For conditions needing frequent, even continual, treatment by nurses or doctors, like otitis media and other "minor ailments", it was claimed that no other institution could provide even comparable arrangements. For vision difficulties or dental defects the clinic could give more suitable treatment, and deal with problems which otherwise went untreated. ${ }^{124}$

118 Board of Education, Annual Report of the Chief Medical Officer for 1918, Cmd. 420, p. 25. BPP 1919, xxi.

${ }_{119}$ See, e.g., Cruickshank, op. cit., note 57 above; McMillan, op. cit., note 102 above; idem, New life in our schools, Manchester, Women's Co-operative Guild, [1909]; Leslie Haden Haden-Guest, The case for school clinics, Fabian Society Tract No. 154, London, Fabian Society, 1911; and Morgan I. Finucane, The feeding, medical inspection and treatment of school children, London, P. S. King \& Son, 1912.

120 Lancet, 1912, i: 1048; Sir Arthur Newsholme, op. cit., note 57 above, pp. 367-72.

121 A. E. Remmett Weaver, 'The Abertillery school clinic', Sch. Hyg., 1911, 2: 522; idem, 'The Abertillery school clinic', Publ. Hlth., Lond., 1910-11, 24: 388-93.

122 LCC, Annual Report for 1914, vol. 3, Public Health, pp. $98 \mathrm{ff}$.

${ }^{123}$ Cruickshank, op. cit., note 57 above, p. 60.

124 Ibid., pp. 58-9. 


\section{J. David Hirst}

The new clinics were sometimes mistrusted by parents at the outset, ${ }^{125}$ but this suspicion later diminished, as did opposition from local doctors, when experience in areas where clinics already existed made it apparent that they posed no threat to the GP's income. ${ }^{126}$

More influentially, the cautious attitude of the Board of Education began to relax as increasing numbers of clinics allowed patterns of "good practice" to be defined and used as guidance by the less experienced authorities. Ralph Crowley, a firm supporter of school clinics, was appointed to the Board's Medical Department in October $1909,{ }^{127}$ and succeeding issues of George Newman's Annual Reports gave increasingly firm backing to clinics. ${ }^{128}$

By the beginning of the First World War the school clinic was the predominant avenue for the treatment of schoolchildren by LEAs. Recent analysis of the effects of the First World War on the British people has suggested that the disruption to civilian medical facilities did not prevent some advances in public health services, though these are not considered to have contributed significantly to improvements in civilian health. ${ }^{129}$ The School Medical Service has not been subjected to a detailed analysis, but the effect of war shortages was to produce a re-ordering of priorities, emphasizing treatment over inspection. As doctors were diverted in increasing numbers to military service, ${ }^{130}$ many LEAs found it difficult to continue routine inspections. At the time of greatest shortage, about 100 authorities had suspended routine inspection. ${ }^{131}$ The policy of the Board was to concentrate resources on the inspection and treatment of children known or suspected to be ill or defective. ${ }^{132}$ The retention of treatment was encouraged by continuation of the grant system. Staff shortages and increased pressure on hospitals resulted in schoolchidren being excluded completely from some hospitals. ${ }^{133}$ As a result, treatment was transferred to school clinics, sometimes newly opened for the purpose. ${ }^{134}$ The shortage of nurses was less severe than that of qualified

\footnotetext{
125 According to a report on the London treatment centres. LCC, Children's Care (Central) SubCommittee, Agenda, 30 May 1913.

${ }^{126}$ Sch. Hyg., 1910, 1: 522.

127 See Ralph Henry Crowley, The hygiene of school life, London, Methuen, 1910.

128 Board of Education, Annual Report of the Chief Medical Officer for 1910, Cd. 5925, pp. 139, 146-65. BPP 1911, xvii. Board of Education, Annual Report of the Chief Medical Officer for 1911, Cd. 6530, pp. 132-47. BPP 1912-13, xxi. Board of Education, op. cit., note 70 above, pp. 166-85.

${ }^{129}$ See, e.g., J. M. Winter, The Great War and the British people, London, Macmillan, 1986, esp. pp. 154-87; Linda Bryder, 'The First World War: healthy or hungry?', Hist. Workshop J., 1987, 24: 141-57.

${ }^{130}$ By 1 January 1918, it was estimated, only 11,482 doctors were continuing in civil practice, with 12,720 in military service. Sir William Grant MacPherson, Medical services: general history, 4 vols., History of the Great War based on Official Documents, London, HMSO, 1921-24, vol. 1, 1921, pp. 144-5. These figures appear to exclude civilian doctors other than GPs. Winter suggests there were 14,718 doctors available to civilians. See Winter, op. cit., note 129 above, p. 170.

${ }^{131}$ Board of Education, Annual Report of the Chief Medical Officer for 1917, Cd. 9206, p. 2. BPP 1918, ix.

132 Board of Education, Circular 899, 1915, 29 March 1915.

133 See, e.g., GROLl, Anglesey CC, Medical Inspection Sub-Committee, Minutes, 19 April 1917.

134 Times educ. Suppl., 10 October 1917, p. 438; 7 November 1917, p. 486. This trend was not uniform throughout the country; nevertheless, in most areas attendances at clinics increased during the War. See Board of Education, Annual Report of the Chief Medical Officer for 1920, Cmd. 1522, pp. 69-70. BPP 1921, xi.
} 
doctors, making it possible to maintain those services, such as the treatment of "minor ailments", usually performed by school nurses. ${ }^{136}$ Even so, provision remained variable:

during $1917, \ldots 39$ authorities . . . had not in operation any approved schemes for securing the medical treatment of defective children in their areas; and . . . in only some 30 areas out of 319 have the authorities made complete provision for the various defects found on inspection. ${ }^{136}$

But these figures reveal how the ostensibly optional power of providing treatment had become, if not at this juncture a universal activity of the education authorities, at least a commonplace one.

The War provided the final stimulus for compulsory provision of medical treatment. Urged on by a memorandum from the Board, ${ }^{137}$ the Reconstruction Committee proposed that "the duty of making adequate provision for medical treatment should be made obligatory upon all Local Education Authorities". ${ }^{138}$ This course of action was by now favoured by Newman, ${ }^{139}$ though he had previously been opposed to compulsion. ${ }^{140}$ But Sir Lewis Selby-Bigge, by now the Permanent Secretary, continued to argue that the time was not yet ripe. ${ }^{141}$ Compulsory provision of treatment facilities was not therefore included in the 1918 Education Bill when first introduced, though the duty of medical inspection and the power to provide treatment were extended to secondary schools. ${ }^{142}$ However, an amendment making the provision of treatment compulsory was moved by Arnold Rowntree, the Liberal Radical MP for York, and in the face of obvious support for the amendment in the House, the President of the Board of Education, H. A. L. Fisher, promised to amend the Bill at the Report stage. ${ }^{143}$

The 1918 Education Act thus laid upon LEAs the duty to provide treatment schemes, although like its predecessor of 1907 the Act referred only to "arrangements ... for attending to the health and physical condition of the children". ${ }^{144}$ This time, there was no doubt as to the meaning of the clause. The 1918 Act simply enacted what was already, in many LEA areas, an established fact. Since 1907, many of the essential features of medical treatment under the School Medical Service had been established. The school clinic had become the most favoured avenue of treatment.

135 Board of Education, Annual Report of the Chief Medical Officer for 1916, Cd. 8746, p. 1. BPP 1917-18, xi.

136 Board of Education, op. cit., note 131 above, p. 39.

137 PRO RECO.1/665, item 35, Board of Education to Reconstruction Committee, p. 6.

138 PRO Cab24/19, 'Memorandum on the Education Bill by the Reconstruction Committee', June 1917. War Cabinet Paper G.T. 1304.

139 PRO Ed24/1369, Education Bill, Minute by Newman, 7 August 1917.

140 PRO Ed24/625, 'Some notes on the Physical Basis of National Education', Memorandum No. 14 on the 1913 Education Bill, by George Newman, 22 March 1913.

${ }^{141}$ PRO Ed24/1369, Education Bill, Minutes by Selby-Bigge, 6 March 1917 and 9 August 1917.

142 Education Bill [1918] as Introduced, [Bill 3], cl. 18. BPP 1918, i.

143 Hansard, House of Commons debates, 5th series, 107: 1770, 1790.

144 Education Act 1918, op. cit., note 11 above. 


\section{J. David Hirst}

CONSEQUENCES OF THE SCHOOL CLINIC

The introduction of medical treatment for schoolchildren raised the issue of who should bear the cost. The Liberal reforms of 1906 to 1914 have been characterized as those of a "social service state", in which aid is directed only to groups in poverty or below minimum levels of income. ${ }^{145}$ The 1906 Education (Provision of Meals) Act provided free school meals for necessitous schoolchildren only. The 1907 Act itself was vague as to who should ultimately bear the cost of any "amelioration and physical improvement" provided, though this was the crux of many of the Parliamentary debates on the 1907 Bill. $^{146}$ This failure to allocate precise responsibility for costs concerned many Conservatives in both central and local government, and they began a campaign to enforce parental contributions except in cases of destitution. Some members of the Moderate group on the LCC were particularly vocal in their support for the principle of parental contributions, ${ }^{147}$ and one of their number, Walter Guinness, also a Tory MP, introduced a private member's Bill in the 1909 session which required parents to pay the cost of treatment unless unable to do so through poverty. The Bill attracted support from members of all parties, (including among the Labour members Ramsey MacDonald), who believed that without the Bill some LEAs would not provide treatment at all because of the cost to the rates. ${ }^{148}$ The Board of Education was privately unhappy at the introduction of the Bill ${ }^{149}$ but felt unable to oppose it in public, noting only that "it would be very unfortunate if in any locality too hard a construction were placed on the provision that the parent must pay if he is able to do so". 150 The 1909 Act, using phraseology almost identical to that of the 1906 Act providing free school meals to the necessitous, imposed a duty on LEAs to charge for treatment provided, unless the parents were considered to be in poverty. ${ }^{151}$

At the outset, the 1909 Act often necessitated the creation of a cumbersome bureaucracy for the administration of school medical treatment, and also accentuated the anomalies and inconsistencies of hospital provision. In London, the introduction of charges meant that parents who were already being directed away from nearer, more convenient hospitals to those with which the Council had made agreements, now found that they were expected to contribute towards the cost, even though other children under school age, and often the parents themselves, might still be eligible for free treatment under the rules of the hospital. ${ }^{152}$ Even where parents had contributed through "Saturday Funds" and similar schemes, they found payment was required for treatment under the School Medical Service. ${ }^{153}$

Furthermore, charges exposed the different expectations of hospital and local authority. Many of the hospitals in London had contracted to treat children referred

\footnotetext{
145 See Asa Briggs, 'The welfare state in historical perspective', Archs Eur. Sociol., 1961, 2: 221-58; Hay, op. cit., note 5 above, pp. 11-13.

146 See, e.g., Hansard, 4th series, 180: $917 \mathrm{ff}$.

147 Lancet, 1909, i: 1071.

148 See Hansard, House of Lords debates, 5th series, 2: 842.

149 PRO Ed50/3, handwritten footnotes to memorandum on 1909 Act, unsigned.

150 Hansard, House of Lords debates, 5th series, 2: 843.

151 Local Education Authorities (Medical Treatment) Act 1909. Public General Acts, 9 Edw. VII., c. 13.

152 Lancet, 1910, ii: 1437.

153 LCC, Children's Care (Central) Sub-Committee, Agenda, 27 January 1911.
} 
by the Council provided they were members of the necessitous poor. Some hospitals, notably Charing Cross and The London, subjected the parents and their children to investigation by their almoners. But the presence of a scale of fees, often varying according to both income and treatment given, implied that some of the children treated were not of the necessitous classes. On the LCC's scale, some relief from the full cost of treatment could be obtained on net incomes as high as $37 \mathrm{~s}$. $5 \mathrm{~d}$. a week, far higher than Rowntree's gross poverty line of $21 s .8 d$. a week for a slightly smaller family in 1901. ${ }^{154}$

Analysis of the scales of charges shows that treatment from the School Medical Service was not generally seen as for the necessitous only, but more a service for all children in public elementary schools, the parents of some of whom were relatively prosperous. The view that all elementary schoolchildren should be eligible for treatment was a further incentive to the establishment of school clinics. The hospitals might insist on a test of destitution, however loosely defined; the clinic would open its doors unambiguously to all children in public elementary schools. In rare instances LEAs with clinics attempted to restrict access to poor children only, but then apparently only in the first years of treatment. At Warrington, it was decided that only children where the family income was $3 s$. per head or less would be treated at all (a higher standard of eligibility than that required by the local infirmary). ${ }^{155}$ The policy was reviewed after it was found that "the thriftless and less deserving were treated at the clinic, while the respectable working man's children were sent to accept it [treatment] at a charitable institution". 156

Charging for treatment and the bureaucracy it created brought problems. Even the simplest system of charges required more administrative time; the LCC's sophisticated graduated scale required the involvement of at least six different officers in the process of assessment and collection of fees. ${ }^{157}$ The practical outcome, as opposed to the symbolic effects of charges, was disappointing. The LCC had collected only $£ 185$ in parental contributions by the end of December, 1910, though costs incurred in assessing and levying charges amounted to $£ 800 .{ }^{158}$

Many LEAs gradually abandoned or ignored their scale of charges. The Board of Education itself did not press for charges to be made, ${ }^{159}$ and was alleged to have actually encouraged their abandonment or non-imposition. ${ }^{160}$ By 1918 the Act was described as a "dead letter". ${ }^{161}$ This was an exaggeration, but statistics collected in the period after the First World War, detailed below, indicate that many LEAs were waiving many or all charges:

\footnotetext{
154 Ibid. This is the scale applying for ringworm treatment for a child in a family of 2 adults and 4 children. Rowntree's poverty line was calculated for a family of 2 adults and 3 children. B. Seebohm Rowntree, Poverty; a study of town life, 4th ed., London, MacMillan, 1902, p. 110.

${ }_{155}$ Wigan C.B.C., Annual Report of the School Medical Officer for 1909, p. 19; Warrington C.B.C., Annual Report of the School Medical Officer for 1910, pp. 16-17.

156 Warrington C.B.C., Annual Report of the School Medical Officer for 1913, pp. 42-3.

${ }^{157}$ LCC, Children's Care (Central) Sub-Committee, Agenda, 27 January 1911.

158 Ibid.

159 PRO Ed50/66, minute on charges for treatment, 15 March 1923.

160 Med. Offr, 1914, 11: 74.

161 Hansard, House of Commons debates, 5th series, 104: 703.
} 
CHARGES FOR MEDICAL TREATMENT $1919-20^{162}$

$\begin{array}{lllll}\begin{array}{l}\text { Providing } \\ \text { spectacles }\end{array} & \begin{array}{l}\text { Minor } \\ \text { ailments }\end{array} & \begin{array}{l}\text { Dental } \\ \text { treatment }\end{array} & \begin{array}{l}\text { Tonsils \& } \\ \text { adenoids }\end{array} & \begin{array}{l}\text { X-Ray } \\ \text { treatment }\end{array}\end{array}$
(1) (2) (3)
(1) (2)
(3)
(1) (2) (3)
(1) (2) (3)
(1) (2) (3)

Areas making some

$\begin{array}{lllllllllllllll}188 & 10 & 12 & 51 & 139 & 20 & 107 & 66 & 37 & 115 & 40 & 55 & 52 & 40 & 118\end{array}$ for some ailments (Total: 210)

Areas not levying a charge

(Total: 83)

Totals

(Seven areas did not provide any form of treatment.)

(1) Areas where this form of treatment was both provided and charged for.

(2) Areas where this form of treatment was provided, but where no charge was made.

(3) Areas where this form of treatment was not provided.

In 71 of the 210 areas shown in the table as levying charges for one or more areas of provision, no parental contributions had been received or recovered during the 1919-20 financial year, although conversely in some areas claiming not to charge, some such payments appeared in the LEA accounts. ${ }^{163}$

Although the central government was not yet willing to concede the principle of free treatment for all, at the local level many authorities seem to have regarded all school children as being suitable candidates for free access to whatever medical care was offered by the School Medical Service. Such decisions were not necessarily rooted in political ideology. The extent to which the parents were likely to acknowledge direct and useful benefit to their children seems also to have been an influence. Thus most LEAs charged for spectacles, and the majority for the removal of tonsils and adenoids. Dental care, X-ray treatment and, because of its relatively low cost, treatment of minor ailments, were less frequently the subject of charge. But the decision not to charge was a policy which was clearly aided by the direct control many of them had over their school clinics. Only with the Geddes axe, economies imposed by the central government, was this situation threatened. ${ }^{164}$

The 1907 Act did not require medical treatment to be provided for schoolchildren, but the expectation that treatment would be given was more widespread than some accounts suggest. The school clinic was not the most obvious, nor indeed at the outset the most favoured vehicle for treatment. Yet by 1918, the majority of LEAs were offering treatment, and most were doing so at least partly through a school clinic system. This was because the clinic offered advantages over other systems for the treatment of schoolchildren, and because it gave LEAs greater freedom to determine the conditions under which treatment was to be offered. In providing this independence for the LEAs, the clinic may have contributed to an isolation of the School Medical Service from the mainstream of public health and general medical provision.

162 PRO Ed50/60, charges for treatment, 1919-20.

163 Ibid. In some cases, however, payment for spectacles might have been a direct transaction between parent and optician, and no money would pass through the LEA's accounts.

164 See PRO Ed50/66, Minute on charging for medical treatment, 7 February 1923. 